\title{
Political Murals as Reflection of Cultural and Ideological Identity: The Case of Istanul's Slum Neighbourhoods
}

\author{
Kültürel ve İdeolojik Kimliğin Yansıması Olarak Politik Duvar Yazıları: \\ İstanbul Gecekondu Mahalleleri Örneği
}

\author{
Senem DOYDUK
}

This paper aims to trace the salient attributes of the selected slum neighbourhoods in Istanbul via political mural themes reflecting sociopolitical (i.e. particularly left wing) identitPhotographing and face-to-face interviews are used as a method held in 6 neighbourhoods due to their central location in Istanbul, which had a dissenting discourse and exhibited this prominence as visible in public spaces through writings and acts. The research was carried out during the architectural idea project carried out during 2015-2016, with open-ended interviews with 27 people who have had the opportunity to record their interviews within the scope of many home visits. Along this path, the issue is tackled on two parallel tracks. Firstly, the urban role of the murals is scrutinized by looking into the relationship between the content of the murals and their location in the urban realm. Secondly, murals are analysed in regard to the concept of consistency of political expression through different media. The practical usage and the view of urban open spaces as a process and product of architecture will be examined together with the cultural symbols drawn on the walls through textual and visual language. The rituals of the left wing political resistance and the ideas of the local communities against the government's attitude towards the neighbourhood are materialized on the murals. This research intends to highlight the connections between the language on the walls and the identity of the residents of slums through an overlay of the language on the wall onto the language created by the use of open urban spaces.

Keywords: Facades, identity; Istanbul; local; political murals; slum.

ÖZ

Bu çalışma, Istanbul'daki seçilmiş gecekondu mahallelerinin göze çarpan niteliklerini, sosyo-politik (özellikle sol kanat) kimliğini yansıtan politik duvar temaları aracılığıla incelemeyi amaçlamaktadır. Inceleme yöntem olarak fotoğrafla belgeleme ve yüz yüze görüşme; Istanbul'daki merkezi konumları nedeniyle, muhalif bir söylemi olan ve bu sözü yazı ve eylemlilikler aracılığıla kamusal alanlarda görünür olarak sergileyen, 1980 'li yıllardan sonra ikinci gecekondu dalgasında gelişmiş direngen 6 mahallede gerçekleştirildi. Araştırma, 2015-2016 yılı süresince gerçekleştirilen mimari fikir projesi sürecinde, çok sayıda ev ziyareti kapsamında ancak röportajları kayıt altına alınma imkanı bulunan 27 kişiyle yapılan ucu açık sözlü görüşmelerle yürütüldü. Çalışma, duvar resimlerini politik ifade amacıyla "mimari yüzeylerin yerel mülkiyeti" perspektifinden açıklığa kavuşturmaktadır. Bu süreçte, konu iki paralel açıdan ele alınmaktadır. Ilk olarak, duvar resimlerinin kentsel rolü, duvarların içeriği ile kentsel alandaki konumları arasındaki ilişkiye bakılarak incelenir. İkinci olarak, duvar resimleri farklı medyalar aracılığıyla siyasal ifadenin tutarlıı̆̆ kavramı göz önünde bulundurularak analiz edilir. Mimarinin süreci ve ürünü olarak kentsel açık alanların pratik kullanımı metinsel ve görsel dil ile duvarlara çizilen kültürel sembollerle birlikte ele alınıp incelenecektir. Sol kanattaki siyasi direnişin çabaları ve yerel toplumun hükümetin tutumuna karşı sahip olduğu fikirler duvar resimlerinde görülebilmektedir. Bu araştırma, açık kentsel mekanların kullanımıyla yaratılan dil ve duvarlardaki dilin örtüşmesinden yola çıkarak, duvarlardaki dil ile gecekondu sakinlerinin kimliği arasındaki bağlantıyı vurgulamayı amaçlamaktadır.

Anahtar sözcükler: Cepheler; kimlik; istanbul; yerel; politik duvar resimleri; gecekondu.

Department of Architecture, Sakarya University Faculty of Art Design and Architecture, Sakarya, Turkey

Article arrival date: July 17, 2018 - Accepted for publication: April 16, 2019

Correspondence: Senem DOYDUK. e-mail: sdoyduk@sakarya.edu.tr

○ 2019 Yıldız Teknik Üniversitesi Mimarlık Fakültesi - @ 2019 Yıldız Technical University, Faculty of Architecture 


\section{Introduction}

The paper takes the urban murals in the slum neighbourhoods as its focus area and intends to analyse them as graphical and textual expression of political identity within urban realm. The paper argues that murals can not only be daily practices of appropriating architectural surfaces, but also be a means of political expression of communal identity which appears to be consistent with other means of political rhetoric. Along this aim and its associated arguments, the paper, first, examines the existing literature on murals to establish these arguments within a theoretical framework. Then, it endeavours to define the political murals in a specific place within the broader framework of murals. Later, the paper follows two parallel tracks: In the first, of the murals are evaluated according to their position within open urban spaces and in the second, they are analysed according to the common formal characteristics with the other means of the specific (i.e. left wing) political expression, particularly the rhetoric.

The study is an attempt to document the political murals on slums with reference to selected neighbourhoods in Istanbul based on their political stance. The study conducts an interpretive analysis based on both direct observation as well as semi-structured and open-ended interviews. The outcomes of these observations and interviews are interwoven with the graphical and formal features to reveal the parallelisms between the political rhetoric of the relevant movement and graphics of political expression as seen through political murals in these neighbourhoods. Regarding the outline given above, the next section intends to revisit the literature on murals from a perspective of their communal role.

\section{The Function of Murals as Art Works and the Role of Political Murals in Slums as Features of Vernacular Culture and Local Identity}

Murals date back to pre-historic wall paintings. They have always been considered as instruments of public communication. Particularly with the rise of Semitic religions, murals have gained a significant role in influencing the larger masses of people although their role is also significant for other religious communities. ${ }^{1}$ Through McLuhan's reading, who asserted that "environment is the message", murals seem to have taken the role of today's mass media. In his seminal work, Understanding Media, McLuhan ${ }^{2}$ defines media as an extension of man. At this point, it is important to emphasize the role of political murals as an extension of community politics. The existing literature, therefore, will be reviewed with an emphasis on the following points; the different status of political murals among other mural types, their textual content, their sym-

\footnotetext{
1 Landres, $1996 . \quad 2$ McLuhan, 1994.
}

bolic meaning, their visibility in urban context and finally their formal and graphical qualities.

Davis $^{3}$ defines a general framework for murals and focuses on the production processes particularly in terms of their creators. This view paves the foundations of the argument of this paper regarding the specific status of the production processes of political murals. The difference between the publicly funded murals and those produced by local communities in opposition to local and central government is clearly understood from David's discussion. From a different yet complementary perspective, Gude and Huebner ${ }^{4}$ discuss the urban aspects of mural works and highlight the notion of their location in urban context. Moreover, Metts's ${ }^{5}$ study raises the issue of community with specific reference to American Muralism. Thus, such studies bring about the issue of different mural types among which those that carry messages regarding a communal identity gains a different status regarding the argument of this paper. In the light cast by this perspective, Moss $^{6}$ emphasizes their role as images of resistance and argues them as unique features of identity negotiation among different parties of the society. Here, Moss discusses that when ethnic community members are empowered in creating their self-representations, the emerging artworks become dominant media images and constitutes new modes and themes of resistance for suppressed communities. In that sense, taken together with their position within the urban space, political murals perform as major actors of political identity struggle within urban realm.

Hence, this section intends to highlight the connections between the language on the walls and the slum residents' local identity by addressing the question of how practice of murals imbricates within the vernacular culture. The active political struggles taking place on the murals represent both the past and the daily memory. ${ }^{7}$ Thus, the murals accumulate the current political identity as a value that remains closely woven into the neighbourhood's history in an abstracted way.

Furthermore, Vernacular art traditions often operate in a similar way to encourage community pride and signal the presence of a community in the city. ${ }^{8}$ Even murals that are not seen as an artwork are still valuable in this type of tradition. In other words, murals teach the local past and make people to remember, create the local memory and show ideas and political rules of a community in society. Murals are always erased but it can be assumed that they are permanent and documented in minds in one way or another. These works, conceived for a place in a limited time span, are like snapshots of a moment in history. ${ }^{9} \mathrm{Me}$ -

\footnotetext{
3 Davis, $2009 . \quad 5$ Metts, $2013 . \quad 8$ Hayden, 1995, p. 38.

4 Gude and Huebner, 6 Moss, 2010.99 Tremlett, 1995.

2000.
} 


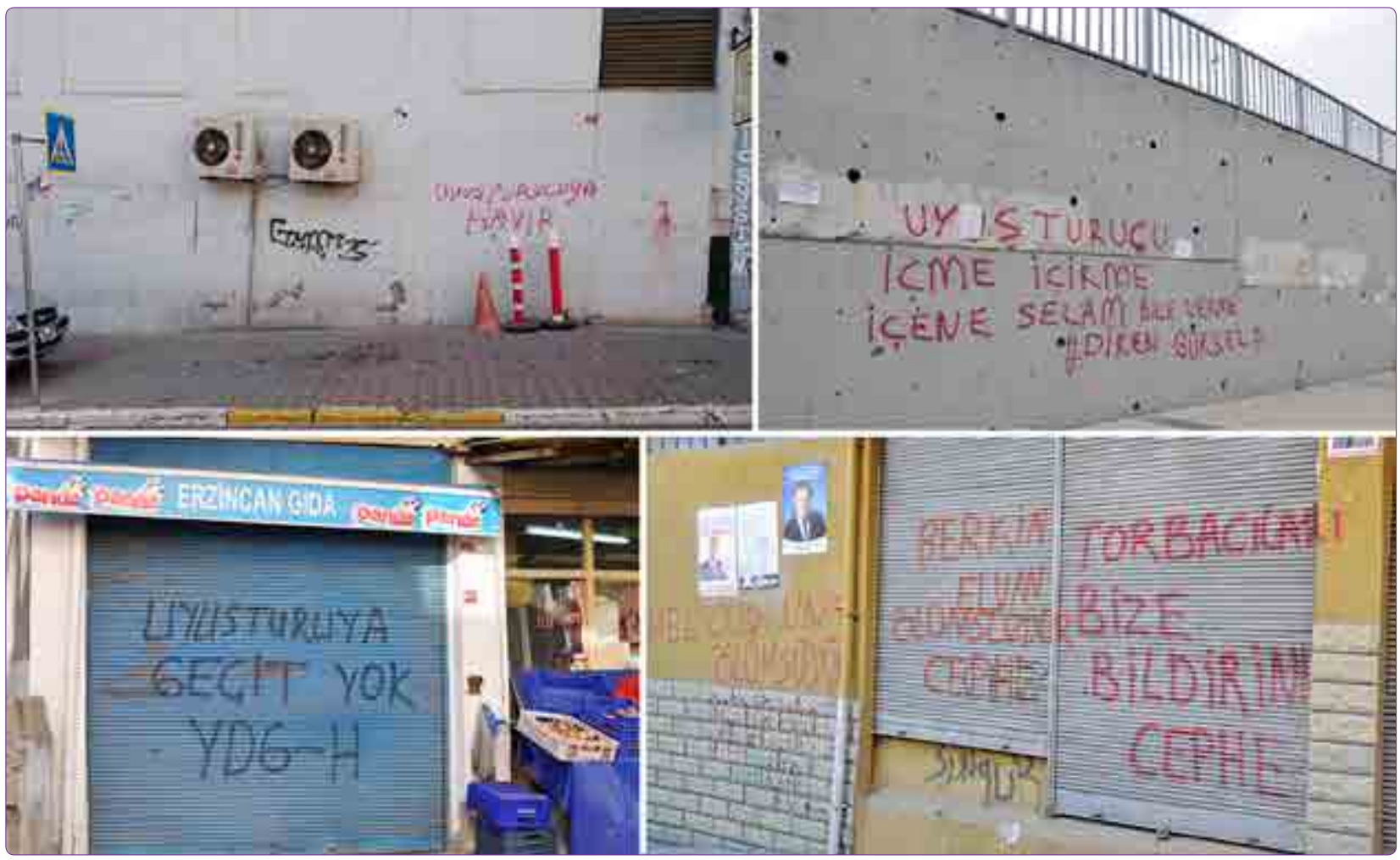

Figure 1. Expressing their ideas about drug dealers. Examples from Çarşamba and Okmeydanı Neighbourhoods

mories of the protests and the local past reconstruct the history of the place again and again whenever the murals are drawn over. These products present evidence of their background that can be erased from the surfaces as a material, but their political principles are not brushed away ideologically. Because, communities may invest greater energy in shoring up, codifying, teaching, and performing cultural practices to ensure their survival, availability, and visibility for their own members and prohibiting access to practice of external cultural modes. ${ }^{10}$

Murals show the character of residents' social solidarity as a self-defined political identity. ${ }^{11}$ Vernacular creativity imprints class consciousness and identity upon the landscape and articulate communal conviviality and social solidarities. ${ }^{12}$ Thus, as a practice of vernacular creation, textual content of murals varies in different neighbourhoods in parallel with the resisting character of the neighbourhood. The variety of the tone of addressing exemplifies this argument. For instance, against the drug dealer gangs, a conservative traditional neighbourhood expresses its opposition by saying: "Do not smoke!" However, in the revolutionist slum neighbourhoods the addressing tone turns out to be more threatening such as: Deliver the dealers to us to be punished! (Fig. 1). In accordance with the alterations in the social values, the language also inevitably changes. While one contends oneself with the suggestion

\footnotetext{
${ }^{10}$ Markusen 2010, p. $187 . \quad{ }^{11}$ Strong, 2010. ${ }^{12}$ Edensor, 2010, p. 14.
}

or recommendation of not smoking in a more passive tone, the other show its power and expose the rights to judge and punish that action strongly and immediately.

Mural texts carry the ideas more than journal or book texts as a performance and a form of ritualized practice with embedded semantic values. This gives more potential power to murals as a bearer of collective memory and tradition. ${ }^{13}$ With the help of local history and national revolutionist heroes on murals, local memory and decisions of persistence can be kept alive. Referring to Eyerman's argument on understanding the tradition and rituals as twin concepts, ${ }^{14}$ the mural production process can be one of the keys to understand the cultural praxis of social movements.

All the images, symbols and ideological slogans on the murals have common legibility as bearers of tradition. The difference is that while encouraging both interpretation and action through symbolic presentation, ideology is more direct in what it does. ${ }^{15}$ Ideology is also composed of images and symbols which provoke emotional response, and which provide a basis for framing or interpreting reality.

Kuper ${ }^{16}$ asserts that culture represents "the continuing ability of groups to make a real difference". It is for that

\footnotetext{
${ }^{13}$ Eyerman, 1999, p. 120.

${ }^{14}$ Eyerman, 1999, p. 120.
} 
reason that "the concept's differential and relativist functions" must be preserved. The ideas, values, morality, and aesthetics are expressed in symbols and texts, and so culture could be described as a symbolic system. ${ }^{17}$ Following Kuper, the murals, too, be the symbols of the neighbourhoods' everyday culture that express their ideas, values, morality and aesthetics. Murals are produced by individuals, but the product affects all the locals where it reciprocally does not only represent the cultural identity but also guide the ideological identity.

A politically-conscious approach to urban preservation must go beyond the techniques of traditional architectural preservation to reach broader audiences. It must also emphasize everyday public life and public memory. This will require reconsidering strategies for the representation of local history in public places, as well as for the preservation of places themselves. ${ }^{18}$

\section{The Political Murals as a Mode of Expression of Communal Identity and Their Mechanisms of Communication}

The present study focuses on political mural works that are in Istanbul's slum neighbourhoods which resist to government's urban settlement policies that demands eviction of local people. It delves into the description of these murals, in detail, to elucidate the difference of these political works on walls from the other mural and graffiti art works in the city. The study tries to create a link between the textual, visual and symbolic language of the political murals and the identity of the vernacular culture. The political murals are examined in 4 sub-sections: i) introduction of the murals in general and their use at the poor neighbourhoods; ii) the locations and the producers of the murals; iii) their semantic meaning; iv) their effects on communal identity.

A Tool to Determine the Identity: Political Murals in General, in the City, and in Slum Neighbourhoods

One of the countless approaches on political mural works considers the practice of drawing on urban walls as vandalism. ${ }^{19}$ According to that approach, it is argued that the buildings are designed with an architectural concern and have their unique visual language. Therefore, an additional visual layer is considered unacceptable and evaluated as a destructive intervention to the architectural facade.

The architectural quality of slums is usually evaluated as poor since they have been produced under low economic conditions. Within years, almost all of them become replaced with apartment blocks as the consequence of the huge urban development wave, particularly in Istanbul. ${ }^{20}$

\footnotetext{
17 Kuper, 1999, p. 227.
}

${ }^{18}$ Hayden, 1995, p. 11.

\footnotetext{
${ }^{19}$ Cohen, 1973.

${ }^{20}$ Sence et al., 2010.
}

Therefore, murals in slum neighbourhoods in Istanbul are the epitome of neo-liberal version of modern architectural style. This paper examines the political murals in the slum neighbourhoods that mostly are located at the heart of the city and built after the second wave of migration in around 1980's from Anatolia ${ }^{21}$ to the neighbourhoods such as Okmeydanı, Sultangazi, K. Armutlu, Çayan, Gülsuyu and Sarıgazi. Today, the physical environment of all slum neighbourhoods in the city share very similar appearances consisting of shanty apartment blocks and that of limited open urban spaces. However, neighbourhoods differ from the rest with murals on their facades. While the architectural language does not directly reflect the identity of the inhabitants by design, the murals of these areas emerge as the only signifier of the current subculture, identity, political view and tendencies of its inhabitants.

Creators of murals as the ordinary people living in these neighbourhoods draw various signs and symbols or write various phrases on walls. These murals can sometimes be produced in larger scales by using huge scaffolds, or, at times, can simply be made as a daily practice even by using spray paints or marker pens. Their political stance and the types of application distinguish them from all other dramatic, funny or exorable writings seen in the city. They are also different from the works of graffiti art also known as street art projects. The process of making these political murals is mostly illegal and some of them are carried out during protests. In this article the murals and their characteristic messages are analysed specifically in relation with the (urban) spaces where they take place. Thus, the following section will address the relation between the content and location of these murals.

\section{The Locations and the Producers of the Murals}

The murals are mostly located on the main roads and squares at the slums, but sometimes surprisingly they can be seen on back streets at hidden corners. The murals are placed not only on the façades of houses but also on the surfaces of electricity panels, billboards, security shutters of shops and even on the roofs (Fig. 2). During daylight hours when the shutters are open the murals are not much visible, but when darkness falls, and the shops are shut, more and more murals appear on the streets (Fig. 3). While some murals show similar traits, some of them depict traumatic narratives. For instance, an attractive painting work which depicts a lacework (dantel işi) takes place on a roof in K. Armutlu neighbourhood. One of the grassroots organizations working in the neighbourhood created a painting covering the whole roof surface with a doily figure to emphasize the rural and domestic character of its owner who was a housewife and yet lost her life during 2001 hunger strike (Fig. 4). Apart from these

\footnotetext{
${ }^{21}$ Yalçıntan and Erbaş, 2004.
} 

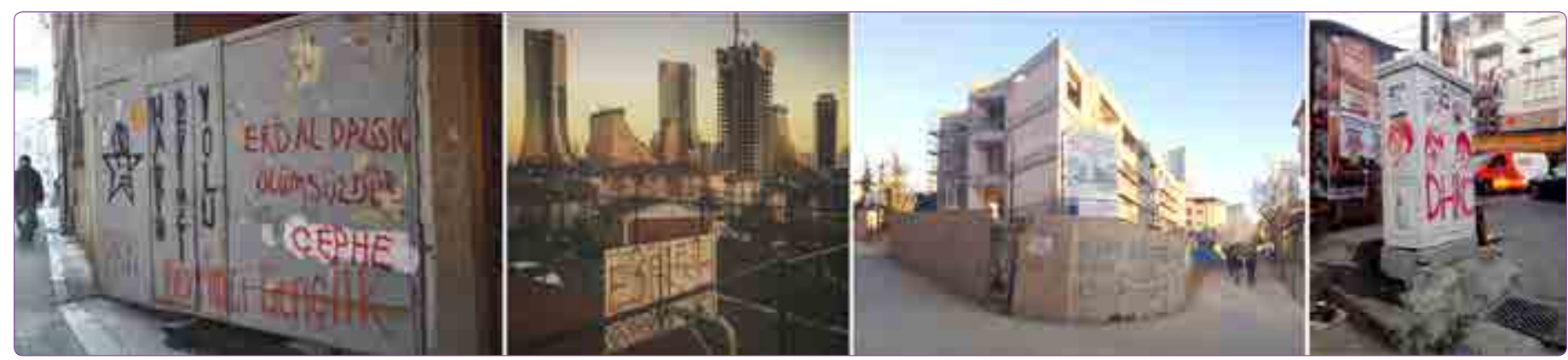

Figure 2. The murals placed on every surface at the slums. Examples from Okmeydanı, Sarıgazi and Gülsuyu Neighbourhoods.

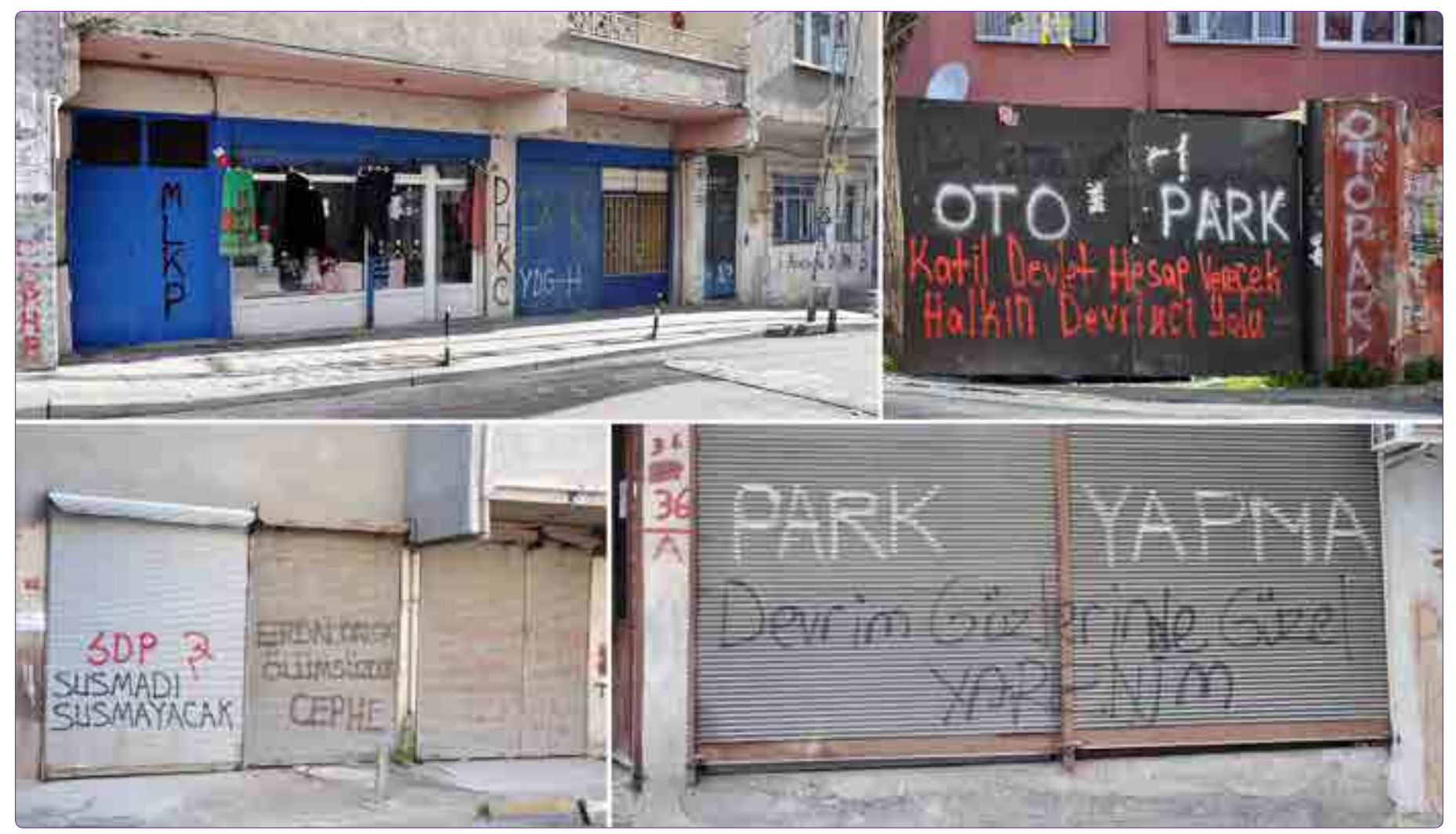

Figure 3. Murals become more visible when the shutters are closed. Examples from Okmeydanı Neighbourhood.

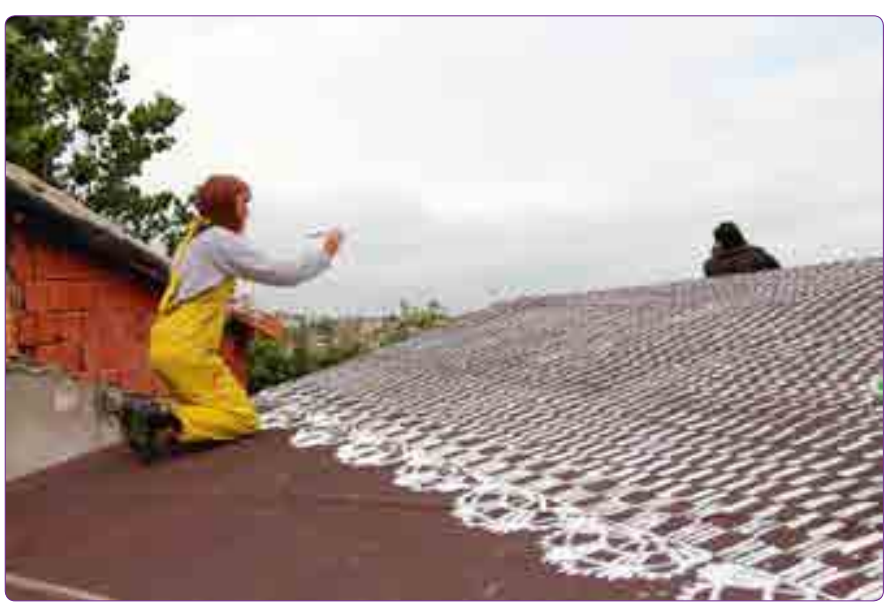

Figure 4. The doily figure emphasizing the rural and domestic character of the owner of the house from K. Armutlu Neighbourhood. unique examples, the height of the murals is mostly limited within arms' reach because of the production process (Fig. 5). Wall murals are usually created at night time with an observer on watch for police surveillance, or during the periods of public protests. After the protests, the neighbourhood reverts to everyday life; the murals on the street walls as the messages from those who spoke remain as the only evidences of what happened on the street hours ago. The murals are the only clues from the insurgences at the slums.

One of the most riveting topics about the producers of murals is; they are ordinary people (the residents) or members of the local political organization. Even monitoring the production process or the interviews with the producers does not easily unveil these links. As it's under- 


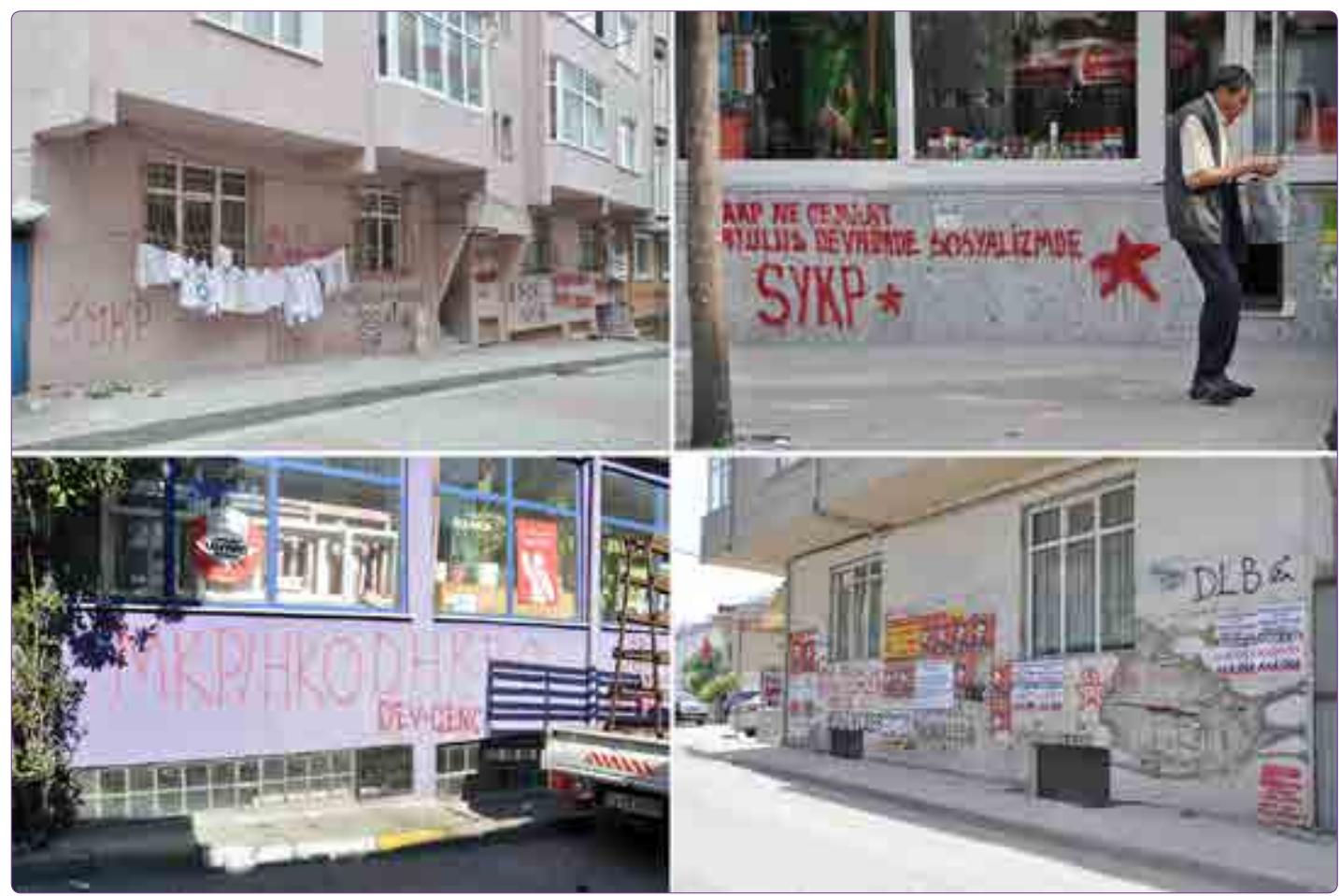

Figure 5. The height of the murals is mostly limited within arms' reach. Examples from Nurtepe Neighbourhood.
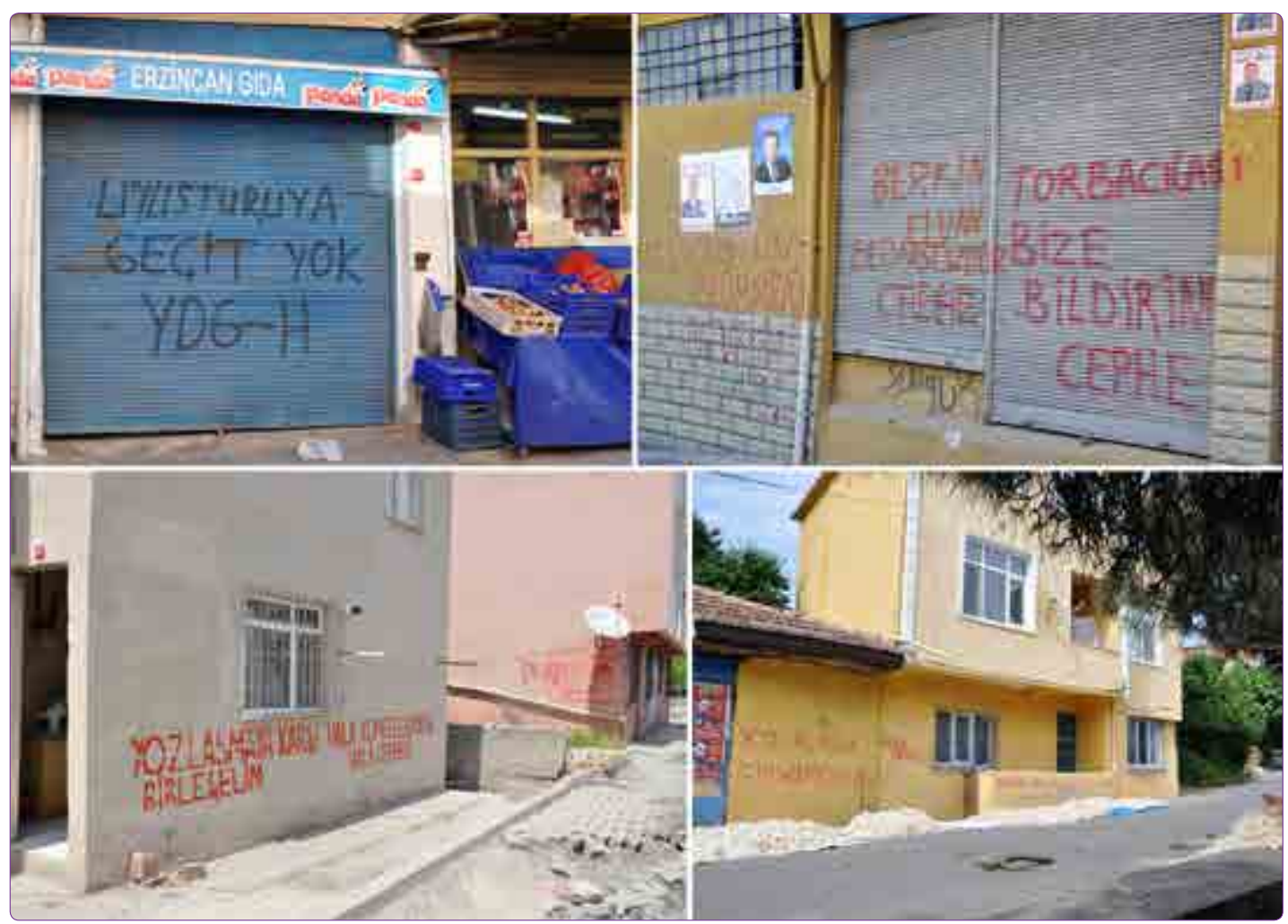

Figure 6. Murals addressing the drug sellers. Example from Okmeydanı Neighbourhood.

stood from open-ended interviews, most of the residents may not be a member of any organization but it's clearly seen that nearly all of them act as a sympathizer. The main conclusion that can be drawn regarding the identity of producers is that mostly the youth create these works. The young generation, also as the residents of the neighbourhood, create the work and the rest, elder generations, help keep the work on their walls. In sum, not all the res- 


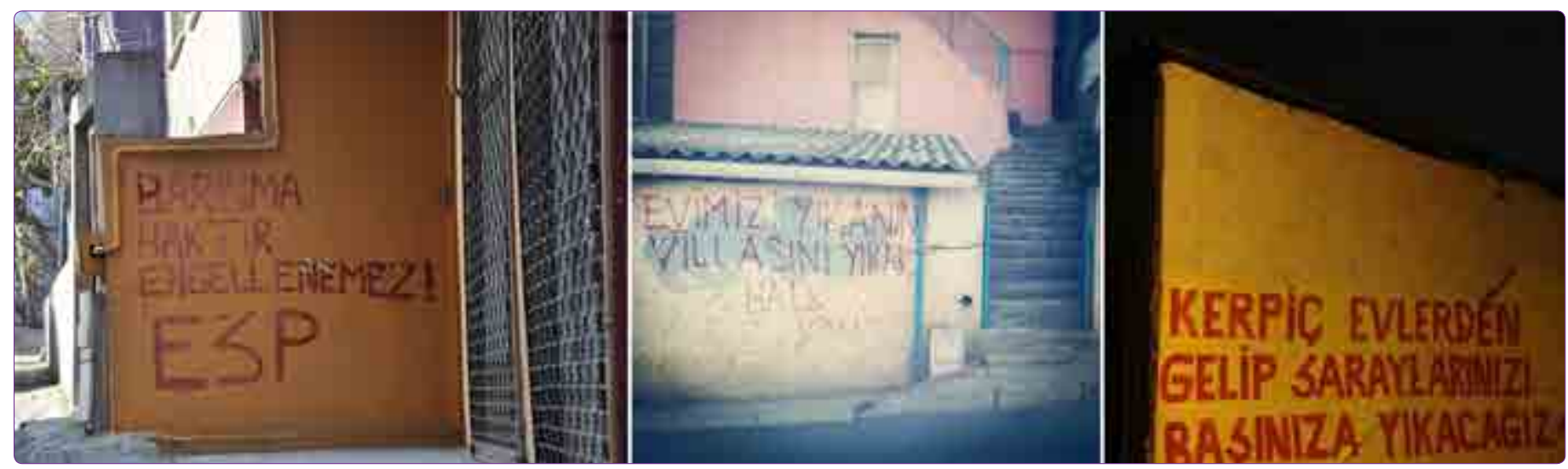

Figure 7. Different organizations with different clues about their ideology. Examples from Okmeydanı and K. Armutlu Neighbourhoods.

idents may give a hand to the actual production process; however, they indirectly become a part of the production process by letting these works to keep on their walls.

\section{The Textual Content and Formal-Stylistic Manners}

of Murals

Hereby, murals will be analysed in terms of their political content, the use of language in the texts, and visual effects to find out their impact on the perception of local people and all society.

\section{Political Content}

The murals and public protests work in cooperation in terms of opposition to authority. In general, contents have an attitude concerning the policies of the government. Mostly, writings offer a solution and give instructions of how to object to the politics and resist against the government by telling the method for actions. The wall writings not only spread the implemented political views but also make announcements about current agenda, upcoming events or memorializing an anniversary from the local or national resisting history. This practice keeps the local memory alive and, at the same time, educates the young generation in terms of the practice of resistance to the prevailing ideological culture. The wall writings can often be intimidating for supporters of government (or non-political public) and remind the punishment rules of organizations against subversive attitudes; "Claim your neighbourhood against the corruption! Inform us about the drug sellers! No pasaran to drugs!" (Fig. 6). Some examples about the political agenda of mural writings are about urban transformation projects as expressed in these sentences: "Sheltering is a right, cannot be precluded! We will demolish the villas of those who demolish our houses!" The two different (One is a far-left legal party of the system while the other is a Marxist-Leninist organization) political discourses that prevail in these neighbourhoods belong to different organizations, and even from their procedural differences, they give clues about their ideological positions
(Fig. 7). Usually, it is a tradition to see the sign of the organization drawn in capital letters at the bottom of the sentence. However, after analysing the murals in detail, the owners of the writings can be recognized from discourse, colours, shape, content of the message and even from the stylistic way of using the wall such as figure-ground relationship.

\section{The Use of Language}

Most of the left-wing organization's tone of the language is threatening; for example "It will be paid off!" The structure of the sentences is in the slogan mode, also used vocally during political demonstrations and public protests. There is no ambiguity in the content of the writing: they

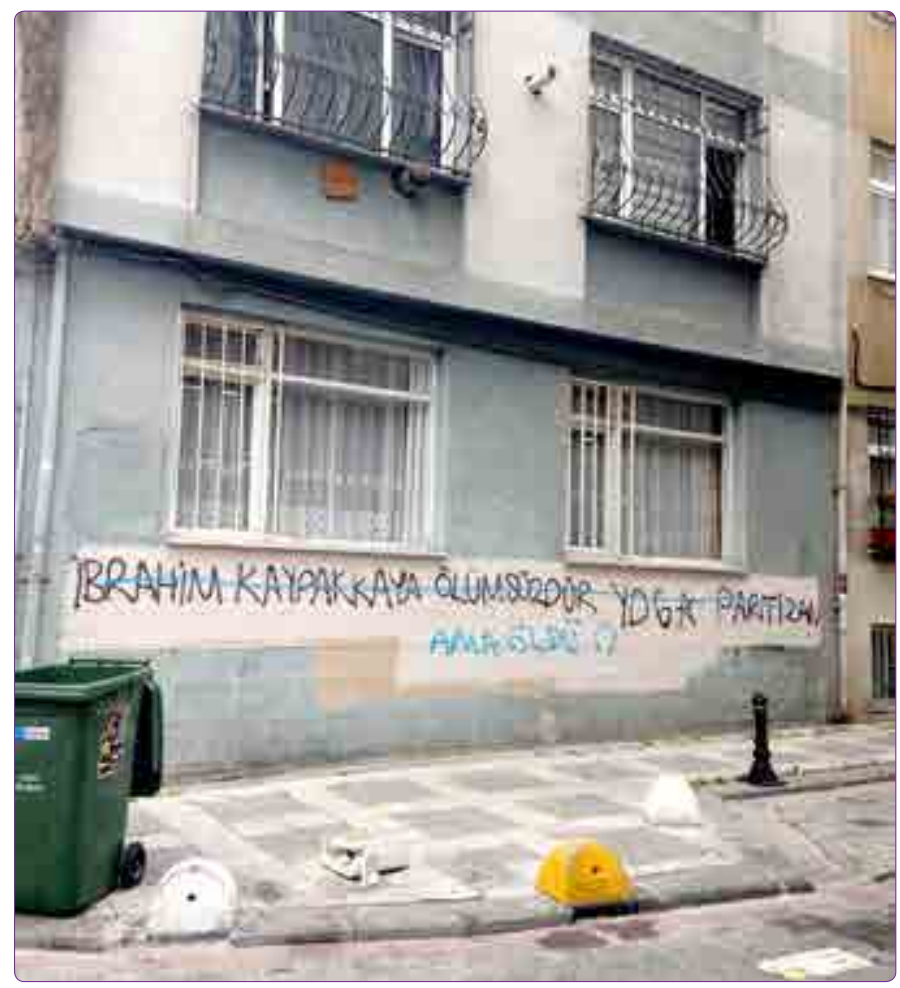

Figure 8. A mural with humour about the immortality of a politic hero. Example from Kadıköy district. 


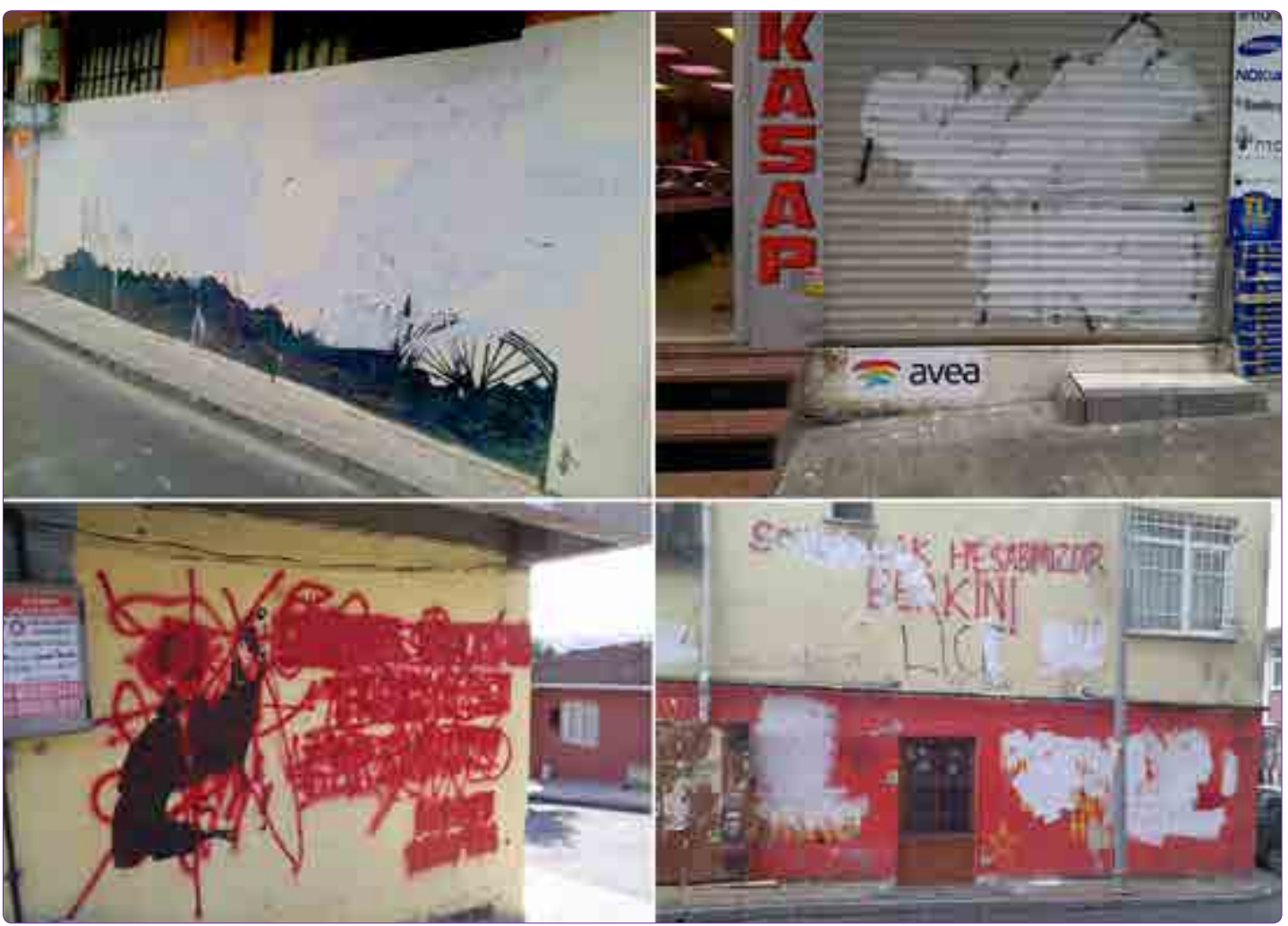

Figure 9. Police intervention to murals. Example from Okmeydanı Neighbourhood.

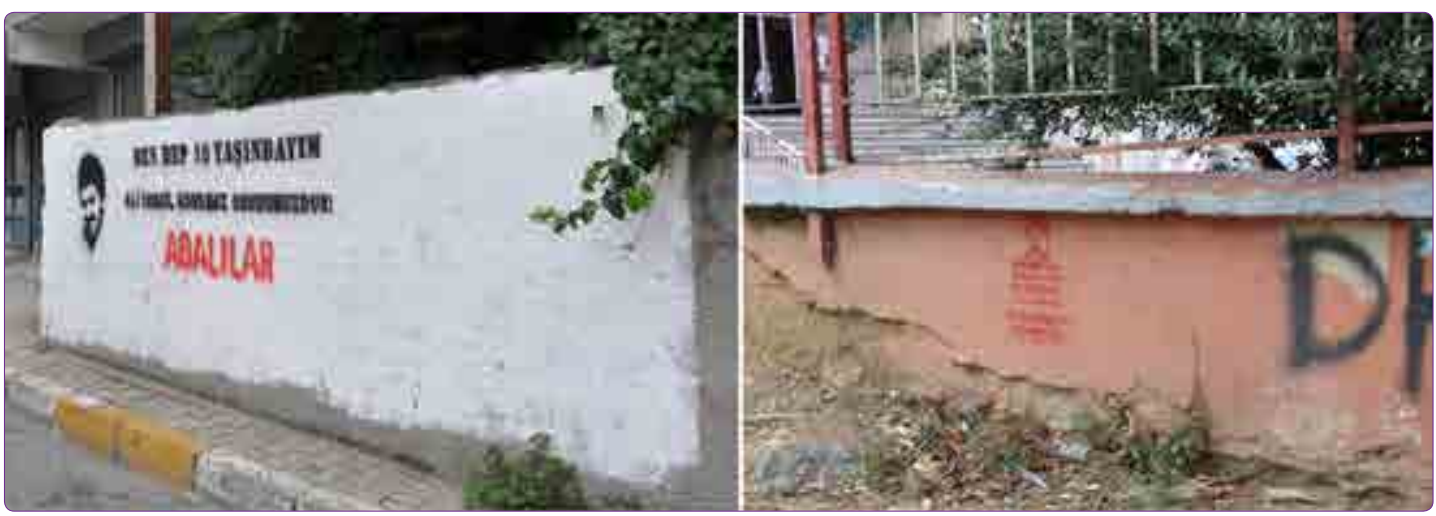

Figure 10. The faces of young boys lost their lives during Gezi Park Protests. Examples from Nurtepe Neighbourhood.

are short, self-explanatory sentences, conveying direct and simple messages in Turkish and sometimes in Kurdish. There are some characteristics that separate the political murals of these slums from the other districts which differ not only in terms of their ideological content but also in the sense of political humour. These short sentences in murals are always very serious and the humour is not a part of the topics. For example, a wall writing in Kadıkoy in Istanbul referring to one of the Left's national heroes as "ibrahim Kaypakkaya is immortal!" was vandalised by an expression written over the preceding sentence: "But he died!" with a smiling face emoticon (Fig. 8) with another layer of spray-can colour. Those kinds of additions are never seen at these slum areas. Only the police attacks can destroy or remove these writings by another overlapping layer of spray (Fig. 9). Otherwise the organizations always pay utmost attention not to cover the sentences of others. Language is often defensive and carefully constructs a narrative $^{22}$ in the slum areas.

\section{Visuality}

As it is mentioned above, murals are mostly in textual or pictorial formats. Most of the pictorial ones are the portraits of political figures. The portrait murals transform the façades into canvases. ${ }^{23}$ Apart from protagonists' figures

\footnotetext{
${ }^{22}$ Miller, 2008, p. $2 . \quad{ }^{23}$ Palmke, 2013
} 


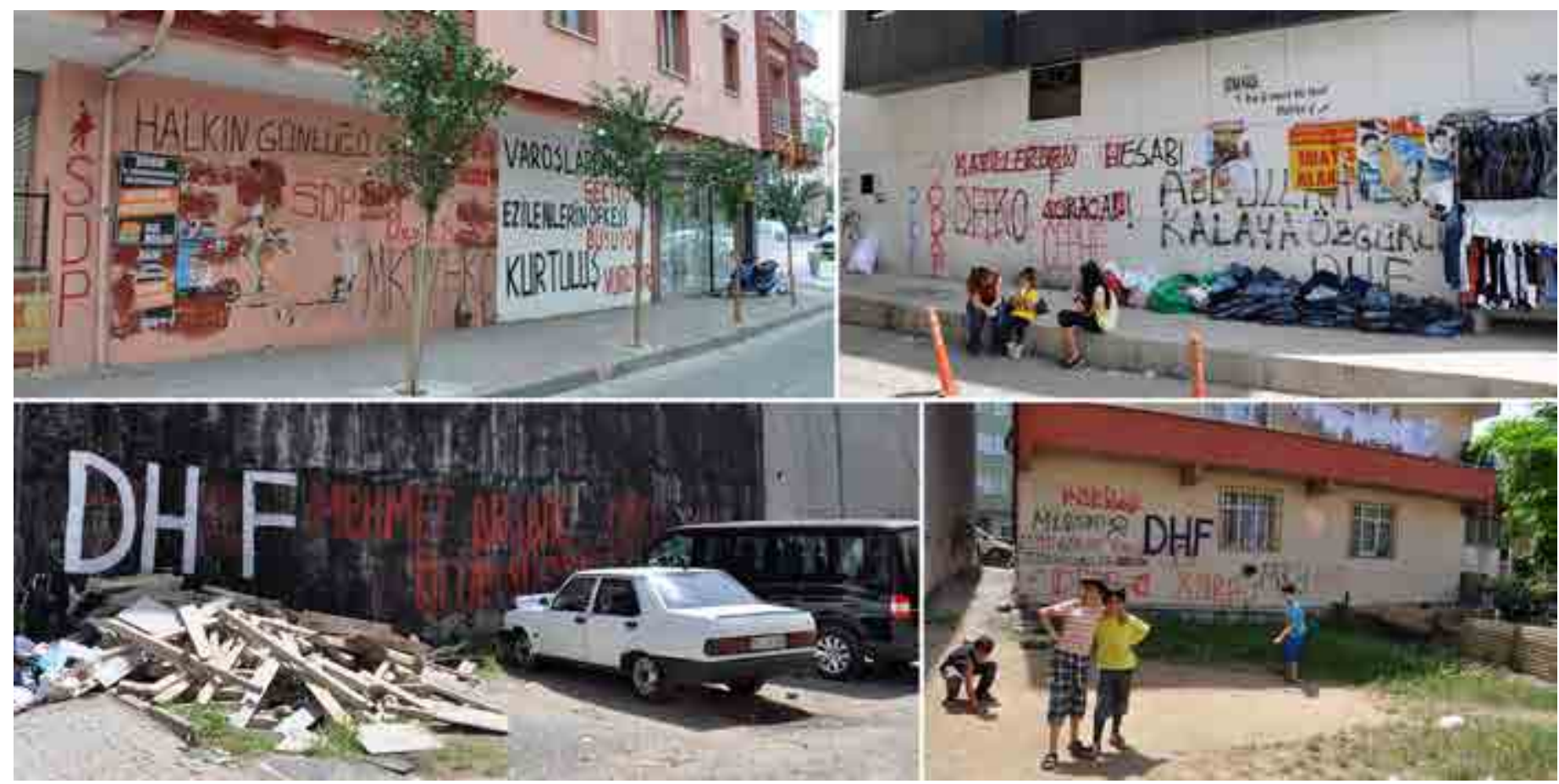

Figure 11. Different organizations or fractions use different colours. Examples from Sarıgazi and Nurtepe Neighbourhoods.

of distant or recent history, faces of some young boys who have lost their lives in the immediate past during Gezi Park Protests in 2013 can also be seen on the walls (Fig. 10).

As Cooper and Sciorra characterize these kinds of works as subway art and indicate that portraiture has emerged as a key feature distinguishing contemporary memorials from subway art; also subway portraits range in style from cartoon line drawings to photorealist depictions. ${ }^{24}$ However, there are no cartoon lines in murals at these specific slums. They are mostly produced by copying from a photo. In that sense, there is no creativity or artwork in these areas. This neutral attitude can be interpreted as a political stance.

The style of graphic design can be analysed in terms of the use of colours, symbols, and the figure-ground relationship from which very interesting details can be observed. These design tools exhibit very consistent similarities within each organization and sometimes have unique characteristics. When the colours are examined, unsurprisingly red emerges as the major colour on the walls as it is the primary base colour of socialism and communism flags. Nevertheless, some other colours are also not rare, in the relation to the different organizations or fractions (Fig. 11). Purple colour of feminism is not seen in any of the murals in these slum areas as it is not regarded as one of the primary political agendas in these neighbourhoods since they find voice in bourgeois districts. Such an analysis of colour presents very interesting conclusions about the spatial segregation and lays bare the keys to that specific

\footnotetext{
${ }^{24}$ Cooper and Sciorra, 1994, p. 77.
}

ideological stance. It can be best observed in Cayan neighbourhood. The neighbourhood has one main road dividing

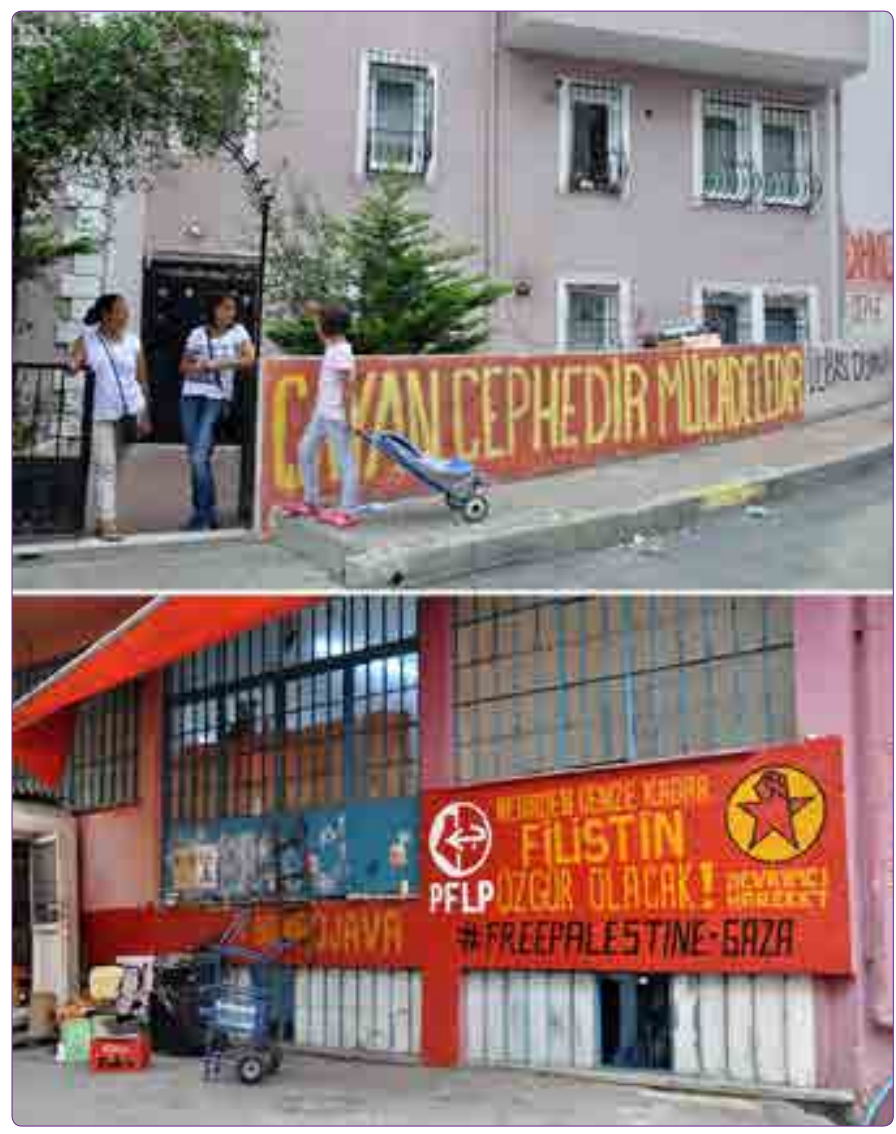

Figure 12. The usage of templates for letterings. Examples from Nurtepe, Sarıgazi and Okmeydanı Neighbourhoods. 


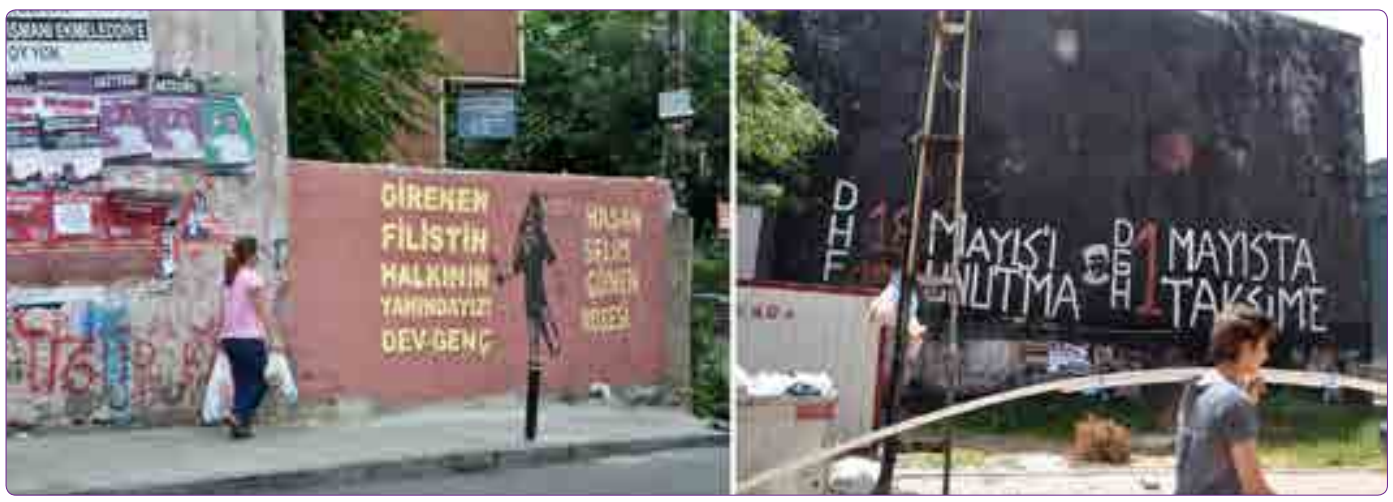

Figure 13. The neighbourhood's surfaces turned out to be canvas. Examples from K. Armutlu and Okmeydanı Neighbourhoods.

the area into two. On one side of this street live the sympathizers of one specific organization the only colour is red; while the other side accommodates all the other groups and parties, which results in a variety of different colours. These political divisions are spatially reflected along the main street. The neighbourhood is politically active and all available of the surfaces are used for murals.

In this culture, dramatic funerary motifs like candles, roses, flowers, hearts or sun are deliberately not used in the portraits or murals of the political leaders. Hammer and sickle and star figure in red or yellow colours are widely used as the symbols of communism.

\section{Framing as a Manner in Mural Design}

Most of the organizations use spray-can or simple brush for drawing. Only one political organization almost always uses a frame behind the writings and paintings. Again, in the works of this group, use of stencils for letterings is very common (Fig. 12). Creation of a base within a frame on the wall by using vivid colours -as mostly red, sometimes white- is one of the salient features of the works of this organization. This graphical attitude seems quite consistent in terms of using the language in all forms, ranging from written to spoken. If visual framing can be evaluated as a key element of their visual language in mural graphic design that shows their ideological principals and cultural traits, similar traces can be found in their rhetoric as the key elements of their political and cultural identity. While members of this organization are trying to decide on a controversial topic during their meetings, they use the sentences as, "Before we start to argue on this topic, we must place our corner stones!" or "We need to argue in corners!" which are not common in spoken language. In these expressions, it is not about a corner literally, an emphasis is metaphorically made on keeping the discussion within a frame, a defined system with sharp limits. Word selection in spoken language and the use of language on the surfaces -in methodological terms- show fascinating similarities and thus consistency.
The façades reflect the inhabitants' rebellious character as the mode of expression of their political world-views. Murals promote reflections on citizenship and local resources of the residents in these neighbourhoods. ${ }^{25}$ Therefore, the study intends to demonstrate how the identity of the resistance of the resistance of the people can be deciphered through the medium of murals.

\section{Impacts of Murals on Insiders/Outsiders}

As mentioned above, use of murals with words and figures affects the neighbourhoods' appearance through colours. Referring to Semper's $\mathrm{s}^{26}$ debate on "architecture as skin", this visual effect is a kind of skin of the environment just like the skin of a human body. Moreover, this kind of skin that is full of murals has a unique effect differing from that of the skins in luxury districts which have clean, smooth, brightly designed facades. The psychological effect seen in these districts through threatening murals is just the opposite of clean surfaces of the bourgeois districts.

Murals deliberately serve to disturb outsiders, meanwhile rejuvenating the neighbourhood. ${ }^{27}$ The facades start to talk by turning out to be more colourful surfaces (i.e. urban skins). The murals change the usually mundane appearance of these slum neighbourhoods to something more conspicuous and compelling (i.e. more animate and alive) for public view (Fig. 13).

\section{Psycho-Geographical Effect}

It is of interest how this urban skin makes an impact in the perception of divergent social groups regarding the political identity of the neighbourhood. Therefore, in addition to both the observation and graphical documentation of the murals and observation of the responses of the people to the murals in place, the views and oral expression regarding the effects on these murals are also recorded. As mentioned above, the study is conducted through open-ended interviews with 1 . local men; 2 . local women; 3. members of a political or civil organization; 4. children

\footnotetext{
${ }^{25}$ Gonzalez et al., 2014. $\quad{ }^{26}$ Semper, 2004. $\quad{ }^{27}$ Halsey and Pederick, 2010.
} 
from the neighbourhood; 5 . family members of Hasan Ferit Gedik (a young boy who lost his life during Gezi Protests); 6. visitors/outsiders (leftist); 7. visitors/outsiders (rightist) on all the selected neighbourhoods. Some of the starting questions are as follows: How do writings affect you? Do you like or dislike them? Do you prefer any figure to be on murals? The answers from different neighbourhoods show similarities. Again, a few samples from the answers given to these questions are as follows: "We don't see them at all. We got used to it. We look but we don't see. They place the announcements but until my neighbours remind me of the hour of the meetings, I never remember. I am very busy. I have lots of work to do in a day, should I check each corner." "There was a police raid during which they covered the wall writings by using spray-can and few days passed, it has not been renewed by young guys and I felt uncomfortable." "When we make a grammar mistake, lots of people warn us about the grammar." When I asked about a topic and wanted to learn if that subject is in their agenda or not, the member of the organization answered: "If you need that mural in that topic for your research, I may easily write it for you sister!" "It's something like having him still around." "I feel more confident; I support it." Hence, the answers help proving the argument on how much local people associate themselves and their communal identity with the murals expressed on the physical skin of their immediate environment.

Murals are created as the medium of opposition: Painting of exterior murals provide people to start reacting against the creative elite -including architects, planners and local authorities- who have been responsible for designing the environment, thereby condemned the layman to a purgatory of institutionalized drabness and homogeneity. ${ }^{28}$ It's obvious that it is a way of giving message about living in their own place as becoming a demurrer part of the community. They have words and ideas they want to express and the resolution to write it on a public area even by taking the wrath of law enforcement.

\section{Conclusion}

The paper analysed the murals in slum neighbourhoods as an expression of political identity in the urban space. For this purpose, murals are examined from two different yet complementary angles. Firstly, murals are evaluated regarding their location within urban space for expressing their political content. Then, murals are investigated as a means of political expression to see their consistency with other modes of political communication in terms of form and content.

The perception of social and political protests in Turkey turned out to be more acceptable by broad communities

\footnotetext{
${ }^{28}$ Cooper and Sargent, 1979, 13.
}

after Gezi Park Protests in June 2013. When thousands of people became aware of police violence through the social networks, the new relations have been established with the local and/or political groups which were used to be called and described as mostly marginal before. The dissemination of mural practices have also been affected from this atmosphere and some writings started to emerge even in some high profile districts of the city. Even though the wall drawings are ephemeral, and the images are transitory, they created a language all over the city of Istanbul. As they can be written and brushed over numerous times, this generated a dynamism on the city surfaces; thus, their meaning and interpretation became more durable. Although wall writings and murals that displays their social opposition can be observed in other different left-wing neighbourhoods, the amount, density and the language of the murals in slum neighbourhoods profoundly differ from those. Unlike those other left-wing neighbourhoods, the reflections of the social structure that cannot be traced from the architectural formation, can easily be followed through murals and writings in slum neighbourhoods. This simplified language can be evaluated as a voice rising from poor neighbourhoods demanding a more meritocratic society. Beside these demands, the unique history and local narratives become also the means in construction of the local identity, which are always produced on the façades in slum neighbourhoods.

Local narrative as a constituent, murals and urban open space collaborate and interleave together. The murals, as slums' response to the zeitgeist in their own style, represent their local resistance history and establish tight connections with the space. Wall writings and murals can be evaluated as place-making practices that affect the daily lives and urban view through not only the messages given but also the direct impacts on public space. As Clifford ${ }^{29}$ asserts that whoever makes the map has the power, the same can be claimed for the murals. The signs at the murals represent the authority, power, and local trace of identity. It further provides the clues of the vernacular practices.

\section{References}

Banksy. (2005) Wall and Piece, London, Century.

Castells, M. (2005) "Grassrooting the space of flows", Ed.: L, Amoore, (editor) The Global Resistance Reader, London, Routledge, pp. 363-370.

Cohen, S. (1973) "Property destruction: Motivies and meanings", Ed.: C, Ward (editor) Vandalism, London, Architectural Press, pp. 23-53.

Cooper, M. and Sciorra, J. (1994) RIP: New York Spraycan Memorials, London, Thames \& Hudson.

Cooper, G. and Sargent, D. (1979) Painting the Town, Oxford, Phaidon.

${ }^{29}$ Clifford, 2011, p. 30. 
Davis, A. P. (2009) New Deal art in Virginia: the oils, murals, reliefs and frescoes and their creators, N.C., McFarland \& Co. Jefferson.

Edensor, T., Leslie, D., Millington, S. and Rantisi, N. (2010) Spaces of Vernacular Creativity: Rethinking the cultural economy, London, Routledge.

Eyerman, R. (1999) "Moving Culture", Ed.: M, Featherstone (editors) Spaces of culture: city, nation, world, London, Sage, pp. 116-137.

Gonzalez, A., Chavez, J. M. and Englebrecht, C. M. (2014) "Latinidad and Vernacular Discourse: Arts Activism in Toledo's Old South End", Journal of Poverty, 18 (1), pp. 50-64.

Gough, P. (2012) Banksy: The Bristol Legacy, Bristol, Redcliffe Press.

Gude, O. and Huebner, J. (2000) Urban Art Chicago: A Guide to Community Murals, Mosaics, and Sculptures, Chicago, Ivan $\mathrm{R}$ Dee.

Halsey, M., Pederick, B. (2010) "The game of fame: Mural, graffiti, erasure", City: analysis of urban trends, culture, theory, policy, action, (14), pp. 1-2.

Hayden, D. (1995) The Power of Place, London, MIT Press.

Kuper, A. (1999) The Anthropologists Account, Cambridge, Harvard University Press.

Landres, J. S. (1996) "Public Art as Sacred Space: Asian American Community Murals in Los Angeles", Religion and the Arts, 1 (3), pp. 7-26.

Markusen, A. (2010) "Challenge, change, and space in vernacu- lar cultural practice", Ed.: T, Edensor, et al. (editors) Spaces of Vernacular Creativity: Rethinking the cultural economy, London, Routledge, pp. 185-199.

Mcluhan, M. (1994) Understanding Media, New York, MIT Press. Metts, E. (2013) Beyond the Walls: Locating "Community" in American Muralism Since 1930, Unpublished M. Thesis, Princeton University Department of Art and Archaeology.

Miller, D. (2008) The Comfort of Thing, Cambridge, Polity Press.

Moss, K.L. (2010) "Cultural Representation in Philadelphia Murals: Images of Resistance and Sites of Identity Negotiation", Western Journal of Communication, 74 (4) pp. 372-395.

Rolston, B. (2011) "Hasta La Victoria!: Murals and Resistance in Santiago, Chile", Identities: Global Studies in Culture and Power, 18 (2), pp. 113-137.

Semper, G. (1989) The Four Elements of Architecture and Other Writings, Cambridge, Cambridge University Press.

Semper, G. (2004) Style in the Technical and Tectonic Arts; or, Practical Aesthetics, Los Angeles, Getty Research Institute.

Sence Türk, S., Korthals, A., Willem, K. (2010) "Institutional capacities in the land development for housing on greenfield sites in Istanbul", Habitat International, 34 (2), 183-195.

Strong, M. (2010) "Big Pictures: Ethnic identity as a mutable concept in New York City street murals", Visual Anthropology, 11 (1-2), pp. 9-54.

Tremlett, D. (1995) Wall Drawings, Barcelona, Fundacio Joan Miro. Yalçıntan, M. C. and Erbaş, A. E. (2004) Mekan ve Siyaset. Birikim Dergisi, (179), s. 28-41. 